\title{
The Efficiency of Public Sector Outsourcing Contracts: A Literature Review*
}

\author{
Paul H. Jensen $^{* *}$ and Robin E. Stonecash ${ }^{\dagger}$ \\ *** Melbourne Institute of Applied Economic and Social Research \\ The University of Melbourne \\ † Australian Graduate School of Management \\ Universities of Sydney and New South Wales
}

Melbourne Institute Working Paper No. 29/04

ISSN 1328-4991 (Print)

ISSN 1447-5863 (Online)

ISBN 0734031718

October 2004

\begin{abstract}
*The authors would like to thank Harry Bloch, John Creedy, Stephen King, Bob Marks, John Quiggin, Jongsay Yong and Beth Webster for helpful comments.
\end{abstract}

Melbourne Institute of Applied Economic and Social Research

The University of Melbourne

Victoria 3010 Australia

Telephone (03) 83442110

Fax (03) 83442111

Email melb-inst@unimelb.edu.au

WWW Address http://www.melbourneinstitute.com 


\begin{abstract}
Outsourcing the provision of traditionally publicly-provided services has become commonplace in most industrialized nations. Despite its prevalence, there still is no consensus in the academic literature on the magnitude (and determinants) of expected cost savings to the government, nor the sources of those savings. After articulating the differences between outsourcing and privatization, this article considers the arguments for (and against) outsourcing and then examines the empirical evidence pertaining to whether any observed savings occur and whether they persist over time. In addition, we examine the existing evidence for the "redistribution hypothesis" and the "quality-shading hypothesis", which critics have used to argue that outsourcing may result in lower government expenditure, but it does so by lowering wages and conditions for employees and lower quality services. Finally, we consider the impact of contract design on outsourcing outcomes. While the nature of the risk-incentive trade-off is well-known in the contract theory literature, some new empirical work has explored the application of this framework to outsourcing in order to understand the impact of the risk premium on outsourcing outcomes.
\end{abstract}




\section{Introduction}

Public sector outsourcing is now a well-established mechanism for government service provision. Despite a great deal of practical experience by governments of all levels, in many countries, there is still relatively little agreement about whether outsourcing is uniformly beneficial or what the magnitude of reductions in government expenditure might be (see Pollitt and Bouckaert 2000). This debate has intensified recently as outsourcing has moved from straightforward tasks such as cleaning and garbage collection to more complex tasks such as providing support services to soldiers in the field. In this article, we review recent developments in our understanding of the determinants of efficient public sector outsourcing arrangements.

Critics of outsourcing claim that it has not consistently delivered on the promised high quality, low cost service. Krugman (2003), for instance, recently observed that:

The U.S. military has shifted many tasks traditionally performed by soldiers into the hands of such private contractors as Kellogg, Brown and Root, the Halliburton subsidiary. The Iraq war and its aftermath gave this privatised system its first major test in combat - and the system failed ${ }^{1}$ (p.17).

Other opponents argue that any savings achieved by outsourcing will be transitory, that outsourcing adversely affects workers' terms and conditions of employment (Quiggin 2002) and that outsourcing may lead to a reduction in the quality of service provision (see Hart, Shleifer and Vishny, 1997). This raises the possibility that the claimed efficiency gains associated with outsourcing are illusory. If observed expenditure reductions are achieved through a reduction in workers' real wages, outsourcing represents a transfer of economic rent from workers to managers rather than an efficiency gain. In this instance, it is not clear that outsourcing results in a net social benefit (Quiggin, 1994).

Nonetheless, there are still numerous success stories (see Savas 2000 for an overview). Advocates of outsourcing claim that it is a powerful policy instrument for

\footnotetext{
${ }^{1}$ An outsourcing arrangement could 'fail' for a variety of reasons: for instance, it could fail to meet either specific performance standards or budgetary savings targets. Existing analyses of outsourcing (including Krugman's) often fail to identify which metric is being used to evaluate 'success'.
} 
reducing public expenditure and improving the performance of government business enterprises because of the high-powered incentives provided by the discipline of the capital market (see Osborne and Gaebler, 1992; and Kettl 2000, for example). Moreover, it is often argued that outsourcing improves efficiency because it introduces competition into the provision of public services and because private firms are relatively free of political interference.

This article examines the empirical evidence on outsourcing and examines recent literature on efficient contracts. Previous surveys of public sector outsourcing (e.g. Domberger and Piggott, 1986) have emphasised competition and ownership as the crucial determinants of efficiency. In this article, we emphasise the importance of (intrinsic and extrinsic) incentives, risk and contract design; factors which have only fairly recently come to the forefront of analysis on public sector reform (see Besley and Ghatak, 2003; Burgess and Ratto, 2003; and Hart, 2003 for recent contributions). In section 2, we consider some of the differences between public sector outsourcing and privatization. Then, in section 3 , we analyse whether the available empirical evidence suggests that outsourcing results in cost savings to the government, what the sources of those savings are, and whether such savings, if any, are persistent over time. Section 4 considers the impact of risk allocation and incentives on the success of public sector outsourcing contracts and finally some conclusions are drawn.

\section{The difference between privatization and outsourcing}

The economics profession has long been interested in the role of the state in the operation of an economy (see Shleifer, 1998 for an overview). While some economies adopted one extreme (complete socialisation of assets in the USSR) or the other (private provision of most goods and services in the US), most economies developed a 'mixed' approach where both privately and publicly owned assets co-existed. The decision to transfer asset ownership from public to private hands is defined here as privatization. The emphasis is on the ownership of physical assets; while nonphysical assets such as human capital are important, they cannot be owned and 
therefore any transfer of human capital to a newly privatised organisation must be voluntary.

Even if the government decides to maintain public ownership of essential assets, the government could transfer responsibility for managing the asset to the private sector, thereby separating asset ownership from service provision. The transfer of service provision from the public to an external organisation (which is typically in the private sector but may also be an in-house team) is defined here as public sector outsourcing. ${ }^{2}$ For reasons of probity and accountability, this transfer is usually done by way of a competitive tender. ${ }^{3}$ Importantly, outsourcing enables the government to retain control over the specification of the service, the management of the contract, and the evaluation of the service provider's performance.

Although privatization and outsourcing have many common characteristics, there are a couple of important differences between the two. First, the arrangements for provision of outsourced goods and services are not forever: the contract will specify a date at which the arrangement ceases, absent a contract renewal. Privatization, however, is generally a once-and-for-all sale of a state-owned asset. The government retains no governance control and no operating risk, although it usually retains regulatory control. Privatized assets can be re-sold (even back to the government), but this is usually caused by financial (or other) problems rather than by contractual obligation. Secondly, outsourcing does not necessarily involve the transfer of any physical assets, whereas privatization does. Outsourcing may, in fact, simply involve the procurement of a specific service - such as cleaning or consulting - that involves trivial physical assets.

Confusion over the distinction between the terms privatization and outsourcing may well stem from the fact that in the US there were few government agencies supplying purely private goods, unlike the UK, Australia, New Zealand and the ex-

\footnotetext{
${ }^{2}$ Of course, there is an analogue to this in the private sector which is often referred to as the "make-or-buy decision". Although it has some relevance to the discussion here, empirical evidence on what determines whether a firm chooses to make or buy a particular service is largely ignored here.

${ }^{3}$ While the design of the tender (which is essentially an auction) has an impact on the outcome, this issue will not be explored in any detail here. The reader is directed elsewhere for more on this issue (see Milgrom, 1989; McAfee and McMillan, 1987; Gomes-Lobo and Szymanski, 2001; and Klemperer, 1999).
} 
communist states. Consequently, there have been few examples in the US of what we describe in this paper as privatization and as a consequence the term privatization is often used in the US to refer to what we describe here as public sector outsourcing. We take the view that public sector outsourcing and privatization are separate, but related, issues.

One common feature of both outsourcing and privatization is that their rationale hinges on the differences in incentives between the public and private sectors. The objective of the private firm is to maximise profit, which can be measured relatively easily and can be tied to a manager's performance. Public-sector organisations, on the other hand, have a more complex set of objectives that involve the maximisation of social welfare. These objectives are hard to measure, thereby weakening the power of incentives in the public sector (see Laffont and Tirole, 1991; Tirole, 1994). Moreover, workers in the public sector are often intrinsically motivated to provide optimal effort, thereby diminishing the need for high-powered incentives (Francois, 2000). High-powered incentive schemes may also be muted in the public sector because managers are not the beneficiaries of increases in asset value. As a result, public managers have little incentive to invest in activities that will either increase asset value (or even prevent a decline in asset value) because they are not able to capture any of that increase (King, 1998). However, the empirical evidence does not universally support the view that public sector organisations are intrinsically less efficient (see Megginson and Netter, 2001; Borcherding, Pommerehne and Schneider, 1982; and Boardman and Vining, 1989).

\section{The empirical evidence on public sector outsourcing}

\subsection{The magnitude of the cost savings}

Aside from any ideological preference for small government, proponents of outsourcing contend that it should result in a more efficient allocation of resources, and thereby reduce fiscal pressure on the government (and thus taxpayers). Unfortunately, the case for outsourcing on the grounds of efficiency-enhancement (and cost reduction) is not easy to substantiate. Much of the difficulty can be 
attributed to the fact that efficiency is difficult to measure in the public sector because of the lack of data on operating costs and outputs. This is partly a result of the fact that, unlike the private sector, cost minimisation has not been until relatively recently a priority in the public sector. But it can also be attributed to the fact that cost allocation techniques are difficult to apply in the public sector because many outputs are joint products. This has changed in recent times with the introduction of activitybased-costing, but the underlying problem is still pervasive. Comparisons of total factor productivity, especially when one small service within a large organisation has been outsourced, are often not possible. There are also difficulties in imputing taxes and determining the appropriate cost of capital for public sector organisations.

As a result, empirical analysis of changes in expenditure following outsourcing at the contract level is not a trivial undertaking. The underlying problem is that there must be a common service outcome in order for comparisons of expenditure to be made. In other words, both the quantity and quality characteristics of the service outcome must be comparable (Jarrell and Skibniewski, 1988). If the comparison being undertaken is longitudinal in nature, the comparability of service outcomes can be done relatively easily provided that the government produced a detailed work specification prior to outsourcing. If the comparison is cross-sectional in nature, however, there is another complication: heterogeneity of outputs. For example, comparing the costs of two separate refuse collectors operating in different areas of the same city may not be valid because they produce outputs of different nature. Differences such as the size of the bin are easy to control for, but the fact that one collection area is much hillier than the other is very difficult to control for. Starr (1988) observes that heterogeneity in service provision outputs is common:

Public and private schools, hospitals, and social services rarely have the same kinds of students, patients or clients... most studies comparing public and private organisations lack any evidence about the quality of services, thereby making it difficult to judge whether lower costs result from greater efficiency or reduced service (pp.6-7).

Indirect costs of production also need to be factored into the expenditure comparison equation. Such costs are incurred whether the service is provided 
internally or externally and should be included in any cost comparisons. These costs should be accounted for by allocating a percentage of such costs to the particular service activity in question (Wisniewski, 1991, 1992). And transaction costs such as writing the specification, drafting the contract, evaluating the tenders also need to be accounted for since it is the sum of production and transaction costs that determines whether any given activity should be conducted within the boundaries of the organization (for more on this see Williamson, 1979, 1985).

Despite the difficulties, there are numerous quantitative studies that have examined whether outsourcing achieves reductions in government expenditure - most of these studies have adopted a cross-sectional approach to analysing contracts let to both public- and private-sector service providers in a particular industry, but many are also case studies of outsourcing exercises. The most commonly studied industries have been the cleaning and refuse collection industries, primarily because these services were frequently outsourced and the outputs are relatively easy to measure (see Edwards and Stevens, 1978; Domberger, Meadowcroft and Thompson, 1986, 1987; Milne and McGee, 1992; Reeves and Barrow, 2000; and Dijkgraaf and Gradus, 2001). Other studies have addressed the issue in industries such as transportation services (Karlaftis and McCarthy, 1999; Nash, 1993; Hensher and Beesley, 1989), maintenance of heavy equipment (Reca and Zieg, 1995), fire protection services (Ahlbrandt, 1973), prison management services (Edwards, 1996), and road maintenance services (Blom-Hansen, 2003). Most of these have found evidence of expenditure reductions, but some studies have demonstrated that expenditure has increased or that the magnitude of savings has been overstated (see Carver, 1989; Woodland, Swords and Hall, 1995; and Holcombe, 1991).

In their study of outsourced refuse collection services, Domberger, Meadowcroft and Thompson (1986) controlled for 12 service characteristics including collection method, frequency of collection, volume of refuse collected and wages. The results from the study demonstrated that local authorities that had put refuse collection to tender and awarded a contract to a private operator achieved savings of 22 per cent on average. Local governments that awarded the contract to the in-house team also 
achieved cost savings of around 17 per cent, which indicates that competition plays an important role in the determination of expenditure reductions. Subsequent work by Szymanski and Wilkins (1993) using the same data set confirmed these findings.

Overall, the majority of empirical research on the subject supports the conclusion that outsourcing results in reductions in government expenditure. The Australian Industry Commission (1996) reviewed 203 international studies of government outsourcing and observed that the extent of savings varied widely, and that in some instances, there was evidence of cost increases following outsourcing. They concluded:

...that no useful 'rule of thumb' exists on the size of the probable impact of [outsourcing] on the costs of delivery. Rather, it appears each instance contains its own unique characteristics which influence its success or otherwise (in cost terms) (p. 127, emphasis added).

Hodge (1999) confirmed the statistical heterogeneity in the level of savings across industries and argued that the overall level of savings from outsourcing is approximately 6-12 per cent. He concluded that "the often quoted 20\%-savings rhetoric appears to be deceptively optimistic on average and unlikely to apply to many public-sector services" (p.464). Therefore, while there is still some ongoing debate about the magnitude of the cost change associated with outsourcing, there seems to be some consensus about the direction of the change (see Quiggin, 1994 on this point).

It is also worth considering whether the observed reductions in expenditure are dependent on whether production is outsourced to a private or a public sector organization. As we have already seen, there is a naïve tendency to assume that the private sector is inherently more efficient than the public sector (see King, 2002 for more on this point). That is, private ownership is necessary and sufficient for improving efficiency. If this assertion is correct, services outsourced to private firms should result in larger cost savings than services outsourced to a public (in-house) team. Once again, the empirical evidence does not support the naïve argument. For example, Domberger et al. (1995) found that the observed savings from outsourcing were achieved irrespective of whether the service provider that won the contract was 
public or private, which led them to conclude that "the effect of ownership (private versus public) on both price and quality was negligible relative to that of competition” (p. 1469).

\subsection{The source of the savings}

The empirical evidence suggests that transferring production to an external source leads to reductions in government expenditure, on average. But it is not clear how these savings have been generated. There are a number of possibilities: substitution of capital for labour, more efficient work practices, economies of scale, innovation, labour shedding, and increases in work intensity are just a few. This section examines empirical evidence for the two most influential arguments: the quality-shading hypothesis and the redistribution hypothesis.

\section{The quality-shading hypothesis}

There are two theoretical foundations for the hypothesis that quality may deteriorate when service production is transferred to the private sector. First, the multi-tasking approach developed by Holmstrom and Milgrom (1991) suggests that in instances where an agent is required to perform a number of different tasks, effort will be allocated to the task that is most easily measured (and therefore rewarded). Thus, the agent may choose to increase productivity at the expense of the quality of the output. Secondly, Hart, Shleifer and Vishny (1997) develop a model where, in a world of incomplete contracts, a private firm has stronger incentives both to reduce costs and improve quality than the public sector. However, the cost-reduction incentive may overwhelm the quality-improvement incentive if quality is difficult to measure (i.e. it is non-contractible). In this instance, the contractor may be able to cut quality without detection (also see King and Pitchford, 1998).

One of the difficulties associated with proving whether quality shading occurs is that quality is difficult to measure. In particular, the measurement of service quality is generally much harder than measuring the quality of a good. Service quality may be identified in terms of performance characteristics, but their assessment may require 
subjective judgement rather than mere accumulation of data. A good example of this is cleaning services: the only way this can be measured is through personal observation and what constitutes a high standard of cleanliness may vary from one observer to another (Domberger and Jensen, 1997). In their critique of Domberger, Hall and Li (1995), Fraser and Quiggin (1999) suggest that performance evaluation may be biased by contractors' attempts to mislead cleaning inspectors.

There have been a number of studies that have found some evidence of quality shading (Cope, 1995; Evatt Research Centre, 1990), but there does not seem to be a consensus on the quality-shading hypothesis. In the Industry Commission (1996) report, they found evidence of both improvements and reductions in service performance levels following outsourcing. They concluded that reductions in quality appeared to be caused by poor specifications and inadequate performance monitoring, which suggests that quality-shading may be a problem of contract design or implementation, and is therefore preventable (Domberger and Jensen, 1997).

The redistribution hypothesis

Another pervasive criticism of outsourcing is that savings are achieved through deterioration in employment conditions rather than an improvement in input utilisation. Thus, savings from outsourcing are transfer payments from workers to managers. Such transfers can take one of two forms: reductions in real wages, or increases in worker effort.

The first significant test of the redistribution hypothesis was made by Cubbin, Domberger and Meadowcroft (1987). Using Farrell's (1957) method of measuring productive efficiency, they showed that a significant proportion of the observed savings were the result of improvements in input productivity rather than reductions in pay. Two factors were identified as improving productive efficiency: changes in the method of payment, and changes in work practices. In particular, 'task and finish' payments - where payments to service providers are based on the estimated number of hours taken to complete a job - were replaced by piece rate pay. 
Quiggin (1994), however, has argued that productivity gains resulting from the replacement of 'task and finish' payment with piecework payments are generally achieved through increased worker effort rather than increases in efficiency. Quiggin is critical of the tendency to assume that productivity gains achieved through increased work intensity are a free good since it assumes that there are unexploited gains from trade to be had. This line or argument is closely aligned with Leibenstein's X-efficiency theory (Leibenstein, 1966), which established the theoretical framework for the existence of worker slack.

The conventional wisdom regarding work intensity is that public-sector workers are lazy; that effort levels in the public sector are sub-optimal. Thus, one of the ways in which productivity could be improved is through reducing labour slack (which is synonymous with increasing work intensity). However, there is no reason to assume that an improvement in productivity is necessarily welfare improving since if it was achieved through increases in work intensity, workers could be worse off than before, so the net welfare benefit may not be positive. Numerous studies have shown that increases in work intensity may also lead to an increase in industrial accidents and repetitive strain injury (see Fairris and Brenner 2001 for example).

Empirical analysis of changes in work intensity have been analysed previously in the economics, sociology and the industrial relations literatures going back to Marx (see Roy, 1952; Edwards and Whitston, 1991; Guest, 1990; Fairris, 2002). Other empirical evidence confirms the hypothesis that outsourcing increases the level of work intensity (Ganley and Grahl, 1988; Haskel and Sanchis, 1995; Kessler, CoyleShapiro and Purcell, 1999). Measurement of work intensity has been done in one of two ways: surveys of workers, or construction of an effort index such as the Percentage Utilisation of Labour index in the UK. Both of these approaches involve significant methodological problems. For example, workers may not report effort levels truthfully when asked because they may have an incentive to over-state their existing effort level (assuming they prefer leisure over work). The problem with the construction of worker effort indices relies on the (subjective) measurement of effort made by work measurement practitioners. 
La Porta and Lopez-de-Silanes (1999) conducted an in-depth analysis of the effects of privatization in Mexico that considered the impact of privatization on workers' real wages. In contrast to the predictions of the redistribution hypothesis, they found that the increase in profitability following privatization did not come at the workers’ expense: mean real wages for employees increased following privatization. A number of other studies, however, have reported reductions in pay and conditions (Cope, 1995; Donahue, 1988; Walsh and O’Flynn, 2000; Domberger, Jensen and Stonecash, 2002). Similarly, Pack (1989) observed that reductions in both wages and fringe benefits were a major portion of the observed cost savings in her study of 15 outsourcing arrangements in US local government.

\subsection{Hold up and the persistence of savings}

Another pervasive difficulty with analysing the efficiency of outsourcing is that contractual relationships are dynamic: the terms of the relationship change over time. Contract prices may be indexed to inflation, or variations to the contract may be required to account for unforeseen events. Even if it were possible to conceive of every possible contingency, it would be prohibitively costly to write them all into a contract. Thus, all contracts are necessarily incomplete. ${ }^{4}$ Under these conditions, simple snapshot (or one-off) comparisons of expenditure are not sufficient to conclude whether outsourcing results in long-term improvements in efficiency because they fail to account for changes in price over time.

Although incompleteness affects all contractual relationships, it presents a particular problem for outsourcing relationships with the private sector. If an unforeseen event occurs, the government will have to approach the contractor and renegotiate a variation to the contract. Private-sector firms - with their incentive to maximise profit - may take the opportunity to increase their price during the course of contract renegotiations. This phenomenon - which involves appropriation of economic rent from the government - is referred to in the literature as "hold-up".

\footnotetext{
${ }^{4}$ The notion of "bounded rationality" - which suggests that humans have limitations on their cognitive capabilities - implies that it is not possible to conceive all future events (March and Simon, 1958). Thus all contracts, with the exception perhaps of the simplest spot transaction, are necessarily incomplete.
} 
The government always has the option of going back to the market if it believes that the private sector is behaving in such an opportunistic manner. However, to do so is costly - there are switching costs associated with re-tendering the service - and the government may prefer to incur small losses associated with contract renegotiations rather than go back to the market. This suggests that, once they have been awarded a contract, a (private-sector) supplier has considerable bargaining power in the event of contract renegotiation. Thus, there may be a fundamental problem in the use of auctions (i.e. competitive tenders) that use price as the sole criterion for evaluating tenderers: awarding the contract to the lowest-price tenderer ${ }^{5}$ may result in savings initially, but may also increase the probability that firms will attempt to hold up the government at a later stage, especially if the contract is highly incomplete. ${ }^{6}$

The possibility that savings from outsourcing will gradually be eroded by privatesector firms that "ratchet up" price over time was first espoused by Williamson (1976) and Schmalensee (1979). Krugman (2002) stated that:

...it's common for private contractors to bid low to get the business, then push their prices up once the government work force has been disbanded. Projections of a 20 or 30 percent cost saving across the board are silly - and one suspects that the officials making those projections know that (p.31).

The classic interpretation of the cause of hold-up is attributed to Williamson (1979, 1985). He argued that people often behave opportunistically, which he defined as "self-interest seeking with guile” (1985, p.47). Such behaviours include blatant forms of deception such as lying and cheating, but also include more subtle forms of deceit such as distortion of information. Although the issue of hold-up is well-established in the economics and business literatures (the GM-Fisher Body example first analysed by Klein, Crawford and Alchian [1978] is often portrayed as the canonical example), there is no empirical work substantiating its existence. In fact, even the Fisher Body case has been disputed as an example of hold-up by Ronald Coase, who had firsthand experience of the relationship (see Coase, 2000). This is not to say that hold-up

\footnotetext{
${ }^{5}$ Most tendering processes now include other evaluation criteria such as experience, financial viability and so on.

${ }^{6}$ Although auctions - in the form of competitive tenders - play an important in the efficiency of public-sector outsourcing arrangements, they will not be covered in any depth here. There is, however, a well-developed literature on the auction design and a new branch of the literature that considers the impact of auctions on procurement decisions (see Bajari, McMillan and Tadelis 2002, for example).
} 
doesn't exist, just that it is difficult to verify empirically. Part of the problem is that it implies intent by one party to extract rent from the other, and intent is difficult to verify empirically using the techniques available to economists - all we observe is the outcome of the behaviour, not the underlying motivation for the behaviour.

Some empirical economists are aware of this problem and have considered solutions. For example, Hubbard (2001) observes that there are a number of reasons why firms appropriate quasi-rents: they may misunderstand the decision at hand; they may make mistakes in their calculations; or they may be attempting to hold up their partner. He states that:

This is a general problem in empirical literature. One may be able to distinguish among these interpretations with data on behaviour before and after contracts are instituted. For example, if delays are out-of-equilibrium events under the "holdup" but not the "mistakes" interpretation, showing that contracts lead to fewer delays is evidence against the former (p.374, emphasis in original text).

Differentiating between these competing explanations is very difficult to do with the existing array of economic tools. One of the obvious difficulties with empirical verification of hold-up is that an observed price increase is not necessarily the result of hold-up. ${ }^{7}$ An agent could increase its price (and thereby increase its accounting profit) in an attempt to get a higher rate of return on capital. In economic terms, this does not constitute appropriation of rent since economic profit includes opportunity costs.

One solution to the hold up problem is through the use of relational (or implicit) contracts, where unforeseen events are dealt with through informal mechanisms (see Macneil, 1974). Since relational contracts are only privately enforceable, they rely on the development of behavioural norms such as trust. ${ }^{8}$ The use of relational contracts has significant implications for organisational boundaries since the existence of norms such as cooperation, honesty, reciprocity and trust may lower costly ex post

\footnotetext{
${ }^{7}$ A similar problem is identified by Demsetz (1982) with regard to empirical analysis of predatory pricing. The difficulty here is distinguishing between a price reduction that occurs as a consequence of normal competition and a price reduction that is directed at driving a competitor out of the market. The former is socially beneficial, while the latter is harmful. Attempts to differentiate these two effects are hampered by the fact that the only difference between the two strategies lies in the underlying motivation of the economic agent, which is unobservable.

${ }^{8}$ Following Posner (1997), a norm is defined as “...a rule that is neither promulgated by an official source, such as a court or a legislature, nor enforced by the threat of legal sanction, yet is regularly complied with...”
} 
negotiations. Until recently, economists have made fairly limited progress in understanding the importance of relational contracts and norms in transactions (see Hart, 2001, however, for a recent contribution). Other recent developments have resulted in widespread acceptance that transactions within and between firms are riddled with relational contracts and that they have important implications for value creation (Kumar, 1996; Zaheer, McEvily and Perrone, 1998), negotiation costs (Artz and Brush, 2000), choice of contract (Corts and Singh, 2002) and integration decisions (Baker, Gibbons and Murphy, 2002). More generally, experimental evidence suggests that norms and social preferences such as fairness and inequity aversion do have an impact on incentives (Fehr and Fischbacher, 2002).

\section{Contract design and efficiency}

Despite the concerted efforts of lawyers, bureaucrats, economists and managers, very few public-sector outsourcing projects turn out the way the government expected. This is simply a reflection of the fact that all projects are inherently risky: contracts are necessarily incomplete, project costs are unknown ex ante and outputs are often intangible. When a government decides to outsource provision of a service, it must determine ex ante how risk should be allocated between parties to the contract (the principal and the agent). An important determinant of project success, therefore, involves the design of the contract. The principal attempts to design a contract that allocates risk to the agent in an efficient manner, whilst providing appropriate incentives for performance (which is typically either cost-reduction or quality improvement). In the following sections, we consider risk and incentive issues associated with designing efficient contracts for outsourcing complex tasks.

\subsection{Risk and incentives}

The observation that efficient contracts involve balancing risk and incentives is wellknown in labour and information economics ${ }^{9}$, but is often overlooked in the

\footnotetext{
${ }^{9}$ There is an extensive body of work on incentives and contract design within firms (for a survey, see Prendergast, 1999), and on optimal contracts in specific labour contexts such as sales (Andersen and Schmittlein, 1984; John
} 
outsourcing literature. In the absence of uncertainty, there is a perfect correlation between output and effort - the principal is able to observe whether the agent dedicated the desired effort level simply through observing the output generated (which is perfectly observable). In this case, contract design doesn't matter. When uncertainty is present, however, the principal is not able to distinguish between the effects of the agent's effort and random events on output. In the presence of uncertainty, therefore, contractual relationships involve a moral hazard problem. In order to overcome the moral hazard problem, the government may transfer risk to the private sector, but this comes at a price since risk-averse firms will charge a premium for bearing risk. As the level of uncertainty increases, the risk premium increases and risk sharing arrangements become more efficient.

In order to illustrate the risk-incentive trade-off, consider the classic case of a government's decision to outsource the design, construction and operation of a rail link between a major city and its international airport. Undertaking such an activity involves a number of different types of risk. First, there is uncertainty associated with the cost of constructing a tunnel underneath the city and surrounding suburbs. The cost of such a tunnel depends upon a number of factors, most of which are unknown prior to construction. The contractor may, for example, find that the excavation is more complex (and therefore costlier) than expected because of unforseen rock formations in the path of the tunnel. Secondly, there is technological uncertainty about the design and construction of new trains. ${ }^{10}$ Thirdly, there is demand uncertainty: demand for the new service is unknown ex ante since it depends upon demand for air travel, the quality, speed and price of the new service. Thus, future revenue streams - which depend upon the number of passengers that use the service are also uncertain.

In order to design an efficient contract, the government must identify and allocate these risks appropriately. This, however, is not an easy task. Consider the effects of

\footnotetext{
and Weitz, 1989), executive employment (Aggarwal and Samwick, 1999), manufacturing (Lazear 2000) and agriculture (Allen and Lueck, 1992, 1999). There is also a considerable literature on contractual relationships between a firm and a franchisee (Brickley, Dark and Weisbach, 1991; Lafontaine, 1992).

${ }^{10}$ For example, in the construction of the trains for the Sydney airport link, there was no space in the compartments for luggage - a distinct disadvantage for travellers wanting to take luggage to the airport.
} 
uncertain demand. The government wants to provide the contractor with incentives to build and operate a high-quality train service that attracts passengers to the service, since rail travel has many positive externalities. This suggests that the Government may choose to transfer the risk of uncertain future revenue streams to the private sector because this provides a strong incentive for the firm to engage in effort to increase patronage. This could be achieved by implementing a payment mechanism that rewards the contractor for passenger numbers above a certain level, indicating passengers were choosing the rail link over alternative transportation modes (taxis, buses, and private cars).

This appears to be a simple solution to the problem. However, there are a couple of factors that this solution does not account for. First, if the level of demand uncertainty is high, the contractor will charge a high risk premium, which will negate some of the benefits of transferring this risk to the contractor. Secondly, the agent's incentive to increase patronage levels is weakened by the fact that demand for the airport rail service also depends on other (exogenous) factors such as the demand for air travel. Even the cleanest, most efficient airport rail service will have trouble attracting more passengers if the demand for air travel falls because of the increased threat of hijacking. Forcing the contractor to bear exogenous risk weakens performance incentives since there isn't a perfect correlation between effort and output.

Standard contract theory distinguishes three types of contracts: fixed-price, costplus and incentive contracts. Fixed-price contracts provide high-powered incentives for productive efficiency since the agent is the residual claimant. Thus the agent is rewarded for any cost-reducing effort it invests in (Laffont and Tirole, 1993). Fixedprice contracts also provide low-powered incentives for quality since the agent can increase profit by reducing quality, especially in instances where certain quality characteristics are non-contractible or the agent has to allocate effort between different tasks (Holmstrom and Milgrom, 1991; Hart, Shleifer and Vishny, 1997). Thus, fixed-price contracts may be more susceptible to the problem of quality shading. 
Cost-plus-fixed-fee contracts provide low-powered incentives for productive efficiency, leading to the moral-hazard problem. However, cost-plus contracts are free from the quality-shading effect. In fact, cost-plus contracts often lead to 'gold plating', where the agent produces the highest quality possible because they are reimbursed for all their effort. Thus, cost-plus contracts are often used for contracts where quality is important or where the task is extremely complex (Crocker and Reynolds, 1993), and when there is a high probability of costly contract renegotiation (Bajari and Tadelis, 2001). In an incentive contract, the agent is paid a fixed fee as well as a pre-determined fraction of all costs incurred by the agent. In effect, there is a continuum of different contracts (McAfee and McMillan 1988).

Recent experience with outsourcing of high-risk, complex tasks has brought into question the results of the standard contracting literature. The crucial, but typically implicit, assumption in contract theory is that the incentive contract is costlessly enforceable and that the contractor can be held accountable for delivery of any contracted services, typically through the courts. ${ }^{11}$ However, this is not always the case. The poor service provided by contractors in Iraq (see Krugman 2003) has lead many in the military to question their use. There are two issues - enforceability and accountability. The government can compel those who are conscripted to the army (or have volunteered) to perform certain duties, but cannot so compel a contractor. The following quote from the Financial Times (11/8/03) illustrates both of these issues:

...the growing dependence on such private sector support concerns some military experts. Part of the problem is that contractors are not subject to military discipline and could walk off the job if they felt like it. The only thing the military could do would be to sue the contractor later on - the last thing on the mind of a commander on the battlefield. This is not just an idle possibility. Since the end of the recent war in Iraq, US army officers have complained that their troops suffered poor living conditions because civilian contractors sometimes failed to show up. Even the mail handled by Halliburton was slow to get through.

\footnotetext{
${ }^{11}$ Laffont and Martimort (2002) discuss the limits to enforceability and conclude that self-enforcing contracts are optimal, but the penalty mechanism used is monetary and may not be sufficient to overcome the kind of very high risks associated with military contracting and hence the breach of those contracts.
} 
In such extreme situations, the government cannot enforce the contract in a timely fashion nor is it able to hold them accountable in any meaningful way if the contract failure ultimately results in the deaths of soldiers.

The standard contracting approach suggests that if a contractor is being asked to bear risk, they will incorporate a risk premium into the contract. Again, this is a reasonable (theoretical) solution to a reasonable amount of risk. However, if the risk is extreme (i.e. the kidnapping and/or death of workers working for the contractor), there may not be a risk premium high enough to cover this kind of risk. Another article in the Financial Times (27/7/04) discusses the difficulties contractors are having in recruiting staff to work in war zones like Iraq: "Contractors in Iraq are having to widen their recruitment net after India and the Phillipines banned their nationals from going to Iraq for work, and Kenya urged its citizens to return home, in response to a wave of kidnappings.”

What these examples show is that the standard contracting approaches that have emerged from the economics of asymmetric information may need to be further developed to handle situations of extreme risk. The conclusion of further theoretical and empirical work may be that there are limits the outsourcing of government services - some activities may need to remain in the hands of the state to ensure appropriate accountability and enforceability. Designing an appropriate incentive contract is not sufficient to obtain the desired outcomes.

\subsection{Empirical evidence on the risk-incentive trade-off}

There has been a lot of attention devoted to testing whether the prediction of a tradeoff between risk and incentives holds true in contractual relationships. The evidence on the trade-off is mixed - some empirical work has demonstrated a trade-off, while other research has demonstrated a positive relationship or no relationship (see Lafontaine and Slade, 2001; Prendergast, 2002). Empirical economists have had trouble verifying the predictions of contract theory for a number of reasons. For example, when we observe a correlation between the use of contracts and certain behaviour, we are tempted to infer causality. This inference, however, may be 
erroneous. Consider Lazear's (2000) study on the impact of a change from hourly wages to piece rate pay on a production line. He finds that the change in the contract improved productivity. Chiappori and Salanie (2000), however, point out that the observed correlation may indicate simultaneity rather than causality.

Another empirical difficulty in testing the predictions of contract theory relates to endogenous matching of contracts with agents. The standard contract theory approach to agricultural contracts predicts that risky crops will be associated with sharecropping because this represents a more efficient allocation of risk. This prediction, however, is contingent on the fact that all agents are the same, and that they are all risk-averse. When there are two types of agents (risk-averse and riskneutral) and two types of activities (risky and less risky), it is easy to consider an alternative prediction to the standard contract theory. For example, the risk-neutral agents are more likely to be drawn to risky activities than risk-averse agents (see Ackerberg and Botticini, 2002). The crux of the problem is that risk aversion is not directly measurable. If it were, econometric modelling of the problem would include both risk and risk aversion. Instead, econometricians use proxies for risk aversion such as wealth, which fails to solve the "matching” problem since the riskiness of the crop is still correlated with the unobserved component of risk aversion.

Another possible reason why the risk-incentive trade-off is not appearing in empirical work is that the theory doesn't model incentives accurately. Recent research suggests that intrinsic motivation may play an important role in human behaviour (Frey and Jegen, 2001; Benabou and Tirole, 2003) and, in particular, with the choice of optimal contracts (Murdock 2002). The standard assumption in economics, however, is that only extrinsic motivation matters: humans respond to the provision of pecuniary incentives. By ignoring intrinsic motivation, reciprocity and fairness, economics has constrained itself to a narrow subset of human behaviours which may affect our understanding of contractual relationships (Fehr and Falk, 2002). For instance, the assumption in economics that incentives have a positive effect on both effort and performance is at odds with sociological and psychological research which 
suggests that extrinsic rewards can sometimes have the opposite effect (see Deci, Koestner and Ryan, 1999). As Baron and Kreps (1999) note:

There is no doubt that the benefits of [pay-for-performance mechanisms] can be considerably compromised when the systems undermine workers' intrinsic motivation (p.99).

Acemoglu, Kremer and Mian (2003) demonstrate that government provision may improve the allocation of resources in sectors such as health and teaching services where the distortionary effects of high-powered incentives are most acute. This hypothesis has received empirical support in the teaching context from Jacob and Levitt (2003) and it appears to gaining more currency in understanding the differences in the power of incentives in public and private sector organizations. The implication of this work is that the assumption of simple dichotomous incentives (either high-powered or low-powered) is insufficient to understand the behaviour of economic actors. It seems more plausible that incentives work in different ways in different institutional structures.

\section{Conclusions}

Despite its importance as a public policy issue and the amount of research devoted to it, the determinants of successful public sector outsourcing are still largely unknown. Traditional analyses of the issue have focused on issues relating to competition and ownership as the key determinants of success. However, recent developments have seen a move away from these issues towards issues related to standard theories of contracts. These developments reflect an underlying shift in the services being outsourcing by the government: historically, simple services such as cleaning and refuse collection were outsourced, whereas now more complex services are being transferred into private hands.

The theme of the present article is that the effects of public-sector outsourcing are best seen through two complementary lenses. Firstly, incentives play an important role in the analysis because transferring production from the public to the private sector involves a shift in the fundamental incentive structures faced by employees 
within organisations. It is typically argued that moving from a low-powered incentive structure (like the public sector) to a high-powered one (like the private sector) should result in improvements in productive efficiency. However, this view is somewhat naïve since it implies that the private sector will always be more productively efficient, an inference that is not supported by theoretical or empirical research. Moreover, recent research has emphasised the role of intrinsic motivation in public sector service provision.

Secondly, risk is an important factor to consider because uncertainty is a feature of most production environments and outsourcing necessitates consideration of how this risk will be allocated between the parties. While it is well established in the theoretical literature that transferring risk to an agent involves a trade-off with incentives, this insight has rarely been applied to the analysis of public sector outsourcing. Bearing this in mind, contract design will play an important role in determining the success of outsourcing arrangements.

On balance, the theoretical and empirical evidence presented here suggests that outsourcing does generate reductions in government expenditure. But there a couple of important caveats to this conclusion. The first is that there is some evidence indicating that quality of service may suffer in certain circumstances as a result of outsourcing and that workers may be worse off (at least in terms of their real wage). The second is that the savings may be transitory - although the empirical evidence is thin, there is some evidence to suggest that hold-up is a problem in outsourcing contracts. The third caveat is that some public services may be less suited to outsourcing than others because the expectation that high-powered incentives generate improvements in productive efficiency may be flawed in instances where intrinsic motivation is important. 


\section{References}

Acemoglu, D., Kremer, M. and A. Mian (2003), Incentives in markets, firms and governments. NBER Working Paper 9802, Cambridge, Mass.

Ackerberg, D.A. and M. Botticini (2002), Endogenous matching and the empirical determinants of contract form. Journal of Political Economy 110(3), 564-591.

Aggarwal, R. and A. Samwick (1999), The other side of the tradeoff: the impact of risk on executive compensation. Journal of Political Economy 107, 65-105.

Ahlbrandt, R. Jr. (1973), Efficiency in the provision of fire services. Public Choice 16(Fall), 1-15.

Allen, D.W. and D. Lueck (1992), Contract choice in modern agriculture: crop-share versus cash rent. Journal of Law and Economics 35, 397-426.

Allen, D.W. and D. Lueck (1999), The role of risk in contract choice. Journal of Law, Economics and Organization 15(3), 704-736.

Andersen, E. and D.C. Schmittlein (1984), Integration of the sales force: an empirical examination. RAND Journal of Economics 15, 385-395.

Artz, K.W. and T.H. Brush (2000), Asset specificity, uncertainty and relational norms: an examination of coordination costs in collaborative strategic alliances. Journal of Economic Behavior and Organisation 41, 337-362.

Bajari, P. and S. Tadelis (2001), Incentives versus transaction costs: a theory of procurement contracts. RAND Journal of Economics 32(3), 387-407.

Bajari, P., McMillan, R. and S. Tadelis (2002), Auctions versus negotiations in procurement: an empirical analysis. Working Paper, Stanford University, October.

Baker, G.P., R. Gibbons, and K. Murphy (2002), Relational contracts and the theory of the firm. Quarterly Journal of Economics 117(February), 39-83.

Baron, J. and D. Kreps (1999), Strategic Human Resources. John Wiley and Sons: New York.

Benabou, R. and J. Tirole (2003), Intrinsic and extrinsic motivation. Review of Economic Studies 70(3), 489-520.

Besley, T. and Ghatak, M. (2003), Incentives, choice and accountability in the provision of public services. Oxford Review of Economic Policy 19(2), 235-249. 
Bettis, R.A., Bradley, S.P. and G. Hamel (1992), Outsourcing and industrial decline. Academy of Management Executive 6(1), 7-22.

Blom-Hansen, J. (2003), Is private delivery of public services really cheaper? Evidence from public road maintenance in Denmark. Public Choice 115, 419438.

Boardman, A.E. and A.R. Vining (1989), Ownership and performance in competitive environments: a comparison of the performance of private, mixed and stateowned enterprises. Journal of Law and Economics 32, 1-33.

Borcherding, T.E., Pommerehne, W.W. and F. Schneider (1982), Comparing the efficiency of private and public production: the evidence from five countries. Zeitschrift fur Nationalokonomie (Supplement 2), 127-156.

Brickley, J.A., Dark, F.H. and M.S. Weisbach (1991), An agency perspective on franchising. Financial Management 20, 27-35.

Burgess, S. and M. Ratto (2003), The role of incentives in the public sector: issues and evidence. Oxford Review of Economic Policy 19(2), 285-300.

Carver, R.H. (1989), Examining the premises of contracting out. Public Productivity and Management Review 13(1), 27-40.

Chiappori, P.A. and B. Salanie (2000), Testing contract theory: a survey of some recent work. Invited Lecture, World Congress of the Econometric Society, Seattle, August.

Coase, R.H. (2000), The acquisition of Fisher Body by General Motors. Journal of Law and Economics 43(1), 15-31.

Cope, S. (1995), Contracting-out in local government: cutting by privatising. Public Policy and Administration 10(3), 29-44.

Corts, K.S. and J. Singh (2002), The effect of relationships on contract choice: evidence from offshore drilling. Unpublished research paper, Harvard University, March.

Crocker, K.J. and K.J. Reynolds (1993), The efficiency of incomplete contracts: an empirical analysis of air force engine procurement. Rand Journal of Economics 24(1), 126-146. 
Cubbin, J., Domberger, S. and S. Meadowcroft (1987), Competitive tendering and refuse collection: identifying the source of efficiency gains. Fiscal Studies 8(3), 49-58.

Deci, E. Koestner, R. and R. Ryan (1999), A meta-analytic review of experiments examining the effects of extrinsic rewards on intrinsic motivation. Psychological Bulletin 125(6), 627-668.

Demsetz, H. (1982), Barriers to entry. American Economic Review 72(1), 47-57.

Dijkgraaf, E. and R.H.J.M. Gradus (2001), Cost savings of contracting out refuse collection: the case of the Netherlands. Mimeo, Erasmus University, February.

Domberger, S. and C. Hall (1995), The Contracting Casebook: Competitive Tendering in Action. AGPS: Canberra.

Domberger, S., Hall, C. and E.A.L. Li (1995), The determinants of price and quality in competitively tendered contracts. Economic Journal 105, 1454-1470.

Domberger, S. and P.H. Jensen (1997), Contracting out by the public sector: theory, evidence, prospects. Oxford Review of Economic Policy 13(4), 67-78.

Domberger, S., Jensen, P.H. and R.E. Stonecash (2002), Examining the magnitude and sources of cost savings associated with outsourcing. Public Performance and Management Review 26(2), 148-168.

Domberger, S., Meadowcroft, S., and D. Thompson (1986), Competitive tendering and efficiency: the case of refuse collection. Fiscal Studies 7(4), 69-89.

Domberger, S., Meadowcroft, S., and D. Thompson (1987), The impact of competitive tendering on the costs of hospital domestic services. Fiscal Studies 8(4), 39-54.

Domberger, S. and J. Piggott (1986), Privatisation policies and public enterprise: a survey. Economic Record (June), 145-162.

Donahue, J. (1988), Prisons for Profit: Public Justice, Private Interests. Economic Policy Institute: Washington DC.

Edwards, F.R. and B.J. Stevens (1978), The provision of municipal sanitation services by private firms: an empirical analysis of the efficiency of alternative 
market structures and regulatory arrangements. Journal of Industrial Economics 27(2), 133-47.

Edwards, G. (1996), Public crime, private punishment: prison privatization in Queensland. International Journal of Social Economics 23(4/5/6), 391-408.

Edwards, P.K. and C. Whitston (1991), Workers are working harder: effort and shopfloor relations in the 1980s. British Journal of Industrial Relations 29(4), 593601.

Evatt Research Centre (1990), Breach of Contract: Privatization and the Management of the Australian Local Government. Pluto Press: Sydney.

Fairris, D. (2002), Are transformed workplaces more productively efficient? Journal of Economic Issues 36(3), 650-670.

Fairris, D. and M.D. Brenner (2001), Workplace transformation and the rise in cumulative trauma disorders: is there a connection? Journal of Labor Research 22(1), 15-28.

Farrell, M.J. (1957), The measurement of productive efficiency. Journal of the Royal Statistical Society 120 (Series A, Part III), 253-290.

Fehr, E. and A. Falk (2002), Psychological foundations of incentives. European Economic Review 46(4-5), 687-724.

Fehr, E. and U. Fischbacher (2002), Why social preferences matter - the impact of non-selfish motives on competition, cooperation and incentives. Economic Journal 112, C1-C33.

Francois, P. (2000), Public service motivation as an argument for government provision. Journal of Public Economics 78, 275-299.

Fraser, L. and J. Quiggin (1999), Competitive tendering and service quality. Just Policy 17, 53-57.

Frey, B.S. and R. Jegen (2001), Motivation crowding theory. Journal of Economic Surveys 15(5), 589-611.

Ganley, J. and J. Grahl (1988), Competition and efficiency in refuse collection: a critical comment. Fiscal Studies 9(1), 80-85. 
Gomez-Lobo, A.S. and S. Szymanski (2001), A law of large numbers: bidding and compulsory competitive tendering for refuse collection contracts. Review of Industrial Organization 18(1), 105-113.

Guest, D. (1990), Have British workers been working harder in Thatcher’s Britain? A re-consideration of the concept of effort. British Journal of Industrial Relations 28(3), 293-312.

Hart, O. (2001), Norms and the theory of the firm. NBER Working Paper 8286, May.

Hart, O. (2003), Incomplete contracts and public ownership: remarks, and an application to public-private partnerships. Economic Journal 113, C69-76.

Hart, O., Shleifer, A. and R.W. Vishny (1997), The proper scope of government: theory and an application to prisons. Quarterly Journal of Economics 112, 11271161.

Haskel, J. and A. Sanchis (1995), Privatization and X-inefficiency: a bargaining approach. Journal of Industrial Economics 43(3), 301-321.

Hensher, D.A and M.E. Beesley (1989), Contracts, competitive bidding and market forces: recent experiences in the supply of local bus services Australian Economic Papers 28, 236-245.

Hodge, G.A. (1999), Competitive tendering and contracting out: rhetoric or reality? Public Productivity and Management Review 22(4), 455-469.

Holcombe, R.G. (1991), Privatization of municipal wastewater treatment Public Budgeting and Finance 11(3), 28-42.

Holmstrom, B. and P. Milgrom (1991), Multitask principal-agent analyses: incentive contracts, asset ownership, and job design. Journal of Law, Economics and Organization 7(Special), 24-52.

Hubbard, T.N. (2001), Contractual form and market thickness in trucking. RAND Journal of Economics 32(2), 369-386.

Industry Commission (1996), Competitive Tendering and Contracting by Public Sector Agencies, Report No. 48. Melbourne, AGPS. 
Jacob, B.A. and S.D. Levitt (2003), Rotten apples: an investigation of the prevalence and predictors of teacher cheating. Quarterly Journal of Economics 118(3), 843878.

Jarrell, D.A. and M.J. Skibniewski (1988), Cost comparison model for contracting out government services. Journal of Management in Engineering 4(3), 260-271.

John, G. and B. Weitz (1989), Salesforce compensation: an empirical investigation of factors related to the use of salary versus incentive compensation. Journal of Marketing Research 26, 1-14.

Karlaftis, M. and P. McCarthy (1999), The effect of privatization on public transit costs. Journal of Regulatory Economics 16, 27-43.

Kessler, I., Coyle-Shapiro, J. and J. Purcell (1999), Outsourcing and the employee perspective. Human Resource Management Journal 9(2), 5-19.

Kettl, D.F. (2000), The Global Public Management Revolution: A Report on the Transformation of Governance, Brookings Institution Press: Washington DC.

King, S. (1998), Privatization: does the reality match the rhetoric? University of Melbourne, Department of Economics, Research Paper Number 634.

King, S. (2002) Why privatization? A review of the Australian experience. In Mead, M. and G. Withers (eds.) Privatization: A Review of the Australian Experience, CEDA.

King, S. and R. Pitchford (1998), Privatization in Australia: understanding the incentives in public and private firms. Australian Economic Review 31, 313-328.

Klein, B., Crawford, R.G. and A.A. Alchian (1978), Vertical integration, appropriable rents and the competitive contracting process. Journal of Law and Economics 21(2), 297-326.

Klemperer, P. (1999), Auction theory: a guide to the literature. Journal of Economic Surveys 13(3), 227-286.

Krugman, P. (2002), Victors and spoils. New York Times, 19 November, Section A, p.31

Krugman, P. (2003), Thanks for the M.R.E.s. New York Times, 12 August, Section A, p.17. 
Kumar, N. (1996), The power of trust in manufacturer-retailer relationships. Harvard Business Review November-December, 92-106.

Laffont, J.-J. and D. Martimort (2002) The Theory of Incentives: The Principal-Agent Model.

Laffont, J.-J. and J. Tirole (1991), Privatization and incentives. Journal of Law, Economics and Organisation 7(Special), 84-105.

Laffont, J.-J. and J. Tirole (1993), A Theory of Incentives in Procurement and Regulation. MIT Press: Cambridge.

Lafontaine, F. (1992), Agency theory and franchising: some empirical results. RAND Journal of Economics 23, 263-283.

Lafontaine, F. and M.E. Slade (2001), Incentive contracting and the franchise decision. In Chatterjee, K. and W.F. Samuelson (eds.), Game Theory and Business Applications. Kluwer Academic.

La Porta, R. and F. Lopez-de-Silanes (1999), The benefits of privatization: evidence from Mexico. Quarterly Journal of Economics 114, 1193-1242.

Lazear, E.P. (2000), Performance pay and productivity. American Economic Review 90(5), 1346-1361.

Leibenstein, H. (1966), Allocative efficiency vs. 'X-efficiency'. American Economic Review 56(3), 392-415.

Macneil, I.R. (1974), The many futures of contract. Southern California Law Review 47, 691-738.

March, J.G. and H.A. Simon (1958), Organizations. John Wiley \& Sons: New York.

McAfee, R.P. and J. McMillan (1987), Auctions and bidding. Journal of Economic Literature 25, 699-738.

McAfee, R.P. and J. McMillan (1988), Incentives in Government Contracting. University of Toronto Press: Toronto.

Megginson, W.L. and J.M. Netter (2001), From state to market: a survey of empirical studies on privatization. Journal of Economic Literature 39, 321-389.

Milgrom, P. (1989), Auctions and bidding: a primer. Journal of Economic Perspectives 3(3), 3-22. 
Milne, R. and M. McGee (1992), Compulsory competitive tendering in the NHS: a new look at some old estimates. Fiscal Studies 13(3), 96-111.

Murdock, K. (2002), Intrinsic motivation and optimal incentive contracts. RAND Journal of Economics 33(4), 650-671.

Nash, C.A. (1993), British bus deregulation. Economic Journal 103, 1042-1049.

Osborne, D. and T. Gaebler (1992), Reinventing Government: How the Entrepreneurial Spirit is Transforming the Public Sector. Addison-Wesley.

Pack, J.R. (1989), Privatization and cost reduction. Policy Sciences 22, 1-25.

Pollitt, C. and Bouckaert, G. (2000), Public Management Reform: A Comparative Analysis, Oxford University Press: New York.

Posner, R. (1997), Social norms and the law: an economics approach. American Economic Review 87, 365-369.

Prendergast, C. (1999), The provision of incentives in firms. Journal of Economic Literature 37(March), 7-63.

Prendergast, C. (2002), The tenuous tradeoff between risk and incentives. Journal of Political Economy 110(5), 1071-1102.

Quiggin, J. (1994), The fiscal gains from contracting out: transfers or efficiency improvements. Australian Economic Review 27(3), 97-102.

Quiggin, J. (2002), Contracting out: promise and performance. Economic and Labour Relations Review 13(1), 88-104.

Reca, J.V. and K.C. Zieg Jr. (1995), Privatization - an analysis of contracting out of government-provided services. National Contract Management Journal 26(2), 51-64.

Reeves, E. and M. Barrow (2000), The impact of contracting out on the costs of refuse collection services: the case of Ireland. Economic and Social Review 31(2), 129-150.

Roy, D. (1952), Quota restriction and gold bricking in a machine shop. American Journal of Sociology 27

Savas, E.S. (2000), Privatization and Public-Private Partnerships, Chatham House Press: New Jersey. 
Schmalensee, R. (1979), The Control of Natural Monopolies. Lexington Books: Massachusetts.

Shleifer, A. (1998), State versus private ownership. Journal of Economic Perspectives 12(4), 133-150.

Starr, P.A. (1988), The Limits of Privatization. Economic Policy Institute: Washington DC.

Szymanski, S. and S. Wilkins (1993), Cheap rubbish? Competitive tendering and contracting out in refuse collection: 1981-88. Fiscal Studies 14(3), 109-130.

Tirole, J. (1994), The internal organization of government. Oxford Economic Papers 46, 1-29.

Walsh, J. and J. O'Flynn (2000), Managing through contracts: the employment effects of compulsory competitive tendering. Industrial Relations Journal 31(5), 454469.

Williamson, O.E. (1976), Franchise bidding for natural monopolies - in general and with respect to CATV. Bell Journal of Economics 7, 73-104.

Williamson, O.E. (1979), Transaction-cost-economics: the governance of contractual relationships. Journal of Law and Economics 22, 233-261.

Williamson, O.E. (1985), The Economic Institutions of Capitalism. Free Press: New York.

Wisniewski, S.C. (1991), Analysing the contracting-out of government services: relevant cost-benefit considerations. Public Budgeting and Finance 11(2), 95-107.

Wisniewski, S.C. (1992), A framework for considering the contracting out of government services. Public Personnel Management 21(1), 101-117.

Woodland, L., Swords, I. and C. Hall (1995), Waste disposal: contracting out garbage collection in Sutherland Shire. In Domberger, S. and C. Hall (eds.), The Contracting Casebook: Competitive Tendering in Action. AGPS: Canberra.

Zaheer, A., McEvily, B. and V. Perrone (1998), Does trust matter? Exploring the effects of inter-organisational and interpersonal trust on performance. Organisation Science 9, 141-159. 